

\title{
Rapid Access to New Angular Phenothiazine and Phenoxazine Dyes
}

\author{
Efeturi A. Onoabedje, ${ }^{a} *$ Uchechukwu C. Okoro, $^{a}$ and David W. Knight ${ }^{b}$ \\ ${ }^{\mathrm{a}}$ Department of Pure and Industrial Chemistry, University of Nigeria, Nsukka, Nigeria \\ ${ }^{\mathrm{b}}$ School of Chemistry, Department of Organic Chemistry, Cardiff University, Wales, UK \\ *E-mail: efeturi.onoabedje@unn.edu.ng
}

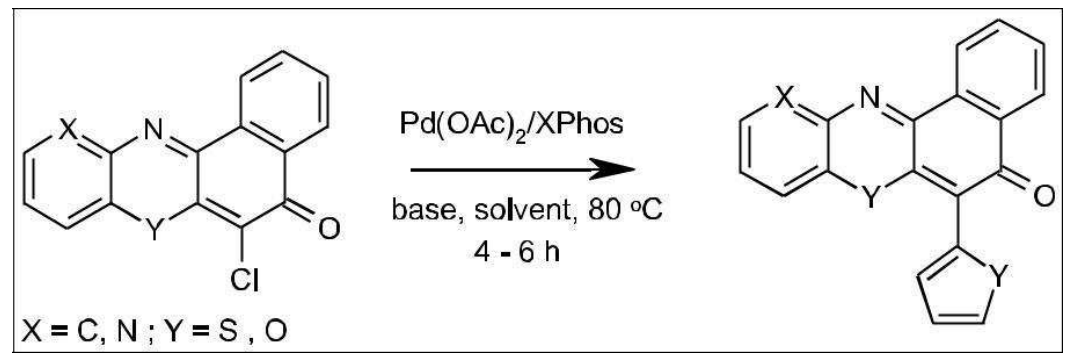

The synthesis of some new thiophenyl-derivatized and furanyl-derivatized phenothiazine and phenoxazine dyestuffs is described. This was achieved by two methods after the synthesis of 6-chloro-5Hbenzo[a]phenothiazin-5-one, 6-chloro-5H-benzo[a]phenoxazin-5-one, and 6-chloro-5H-naphtho[2,1-b] pyrido[2,3-e][1,4]oxazin-5-one intermediates via anhydrous base condensation reaction of 2,3-dichloro1,4-naphthoquinone with 2-aminothiophenol, 2-aminophenol, and 2-aminopyridinol, respectively. The first method involved treatment of tributyl(thien-2-yl) or tributyl(furan-2-yl) stannane with chlorophe nothiazine/chlorophenoxazine under mild basic chemical formula $(\mathrm{CsF})$ and 1,4-dioxane or toluene solvent at $80^{\circ} \mathrm{C}$ to supply dazzling yellow solid in high yields. In the second method, the catalytic system was preactivated in acetonitrile, followed by addition of coupling partners and $\mathrm{K}_{3} \mathrm{PO}_{4}$ to obtain high melting and variety of highly colored products in moderate to high yields. The reaction conditions were compatible with unprotected $\mathrm{N}-\mathrm{H}$ and carbonyl functional groups. The intense colors of these dyes and their ease of re-oxidation of $\mathrm{Na}_{2} \mathrm{~S}_{2} \mathrm{O}_{4}$-reduced derivatives make them suitable as vat dyes. Also, they were found to be good colorants for textiles, papers, paint, ink, soap, polish, candle, and plastic materials.

\section{INTRODUCTION}

The plethora industrial applications of phenothiazine and phenoxazine and their derivatives stimulated our inter-est in synthesizing new derivatives of the parent rings 1 and 2 that may be useful as dyestuffs $[1,2]$.

Compounds 1 and 2 were first prepared by Bernthsen in 1883 and 1887 by thionation of diphenylamine and thermal condensation of o-aminophenol with catechol (2hydroxyphenol), respectively [3,4].

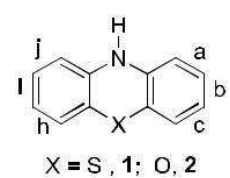

Originally, these compounds and their derivatives were mainly applied as dyes and pigments [5] in industries, but with time, they found wider applications as antioxidant in lubricants and fuel [6-9], polymerization stabilizers [10-12], pesticides/insecticides [13-15], biological stains or labelings [16-19], acid-base indicators [20], and as drugs [21]. Some phenothiazine derivatives, especially Lauth's violet 3 and Methylene blue 4, were known to be commer-cial dyestuffs even before the first synthesis of the parent phenothiazine [1]. On the other hand, Meldola [22] had synthesized large numbers of phenoxazine derived dyes in the last quarter of the last century. Notable among them was Meldola's blue 5 which is a textile, paper and paint colorant.

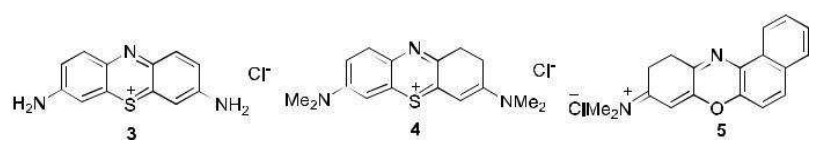

Besides their well-known physiological activity profile, $[23,24]$ because of their reversible oxidative reactions, which give rise to characteristic, deep colored radical cation absorptions, more recently, phenothiazine derivatives have become attractive spectroscopic probes in molecular arrangements for photoinduced electron transfer studies and as scientific motif materials $[25,26]$. Also, recent reports revealed that phenoxazine derivatives are widely applied as organic light emitting diodes [27,28].

Previously, derivatizations of these compounds were achieved by employing classical reactions, which are generally harsh and unamenable to sensitive functional groups. Burgess [29] noted in his review of benzophenoxazine-based dyes for labeling biomolecules that most of the syn-thetic protocols involved elevated temperature and were 
based on procedure that are now over a century old and no contemporary synthetic methods were employed. How-ever, in the recent time, a considerable variety of phenothiazine derivatives had been synthesized from iodo-substituted and/or bromo-substituted phenothiazine precursor via metal catalyzed cross-coupling reactions [30-34]. Grosu et al. [32] reported multistep synthesis of 3,7,10-substituted phenothiazine derivatives in which one of the steps involved Pd-catalyzed Suzuki-Miyaura cross-coupling of bromophenothiazines. Kramer [31] employed the SuzukiMiyaura cross-coupling of bromophenothiazine in the synthesis of (hetero) aryl bridged and directly linked active phenothiazinyl dyads and triads.

In a similar reaction, bromophenothiazines were used as starting materials in the synthesis of phenothiazinyl acid derivatives via halogen-metal exchange and electrophilic borylation route [34] and synthesis of functionalized oligophenothiazines via one-pot bromine-lithium exchangeborylation-Suzuki coupling [33]. Muller [35,36] and his coworkers reported the synthesis of luminescent, redox-active diphenothiazine dumb-bells expanded by conjugated arenes and heteroarenes and 3-acceptor-substituted and 3,7bisacceptor-substituted phenothiazine via Pd-catalyzed crosscoupling of bromophenothiazines. In our previous pa-pers, we have reported the synthesis of new nonlinear polycy-clic aza phenothiazine dyestuffs $[37,38]$. We have also recently reported the functionalization of phenothiazine and phenoxazine ring systems via Pd-catalyzed Suzuki-Miyaura cross-coupling reaction [39]. In continuation of our avid inter-est in developing new dyestuffs, we now report a convenient synthesis of new phenothiazine-derivatized and phenoxazine-derivatized dyestuffs employing Pd-catalyzed Stille cross-coupling protocols.

\section{RESULTS AND DISCUSSION}

Besides 2-chloro-10H-phenothiazine 6 that is commercially available for the palladium(0)/XPhos-mediated Stille cross-coupling, 6-chloro-5H-benzo[a]phenothiazin-5-one 9, 6-chloro-5H-benzo[a]phenoxazin-5-one 10, and 6-chloro5H-naphtho[2,1-b]pyrido[2,3-e][1,4]oxazin-5-one 11 were synthesized by employing the traditional $[40,41]$ anhydrous base-catalyzed reaction of 2,3-dichloro-1,4naphthoquinone 8 with 2-aminothiophenol, 2aminophenol, and 2-aminopyridin-3-ol 7 (Scheme 1).

Influenced particularly by the work of Buchwald and coworkers [42] who applied pre-milled palladium acetate and XPhos catalytic system in successful cross-coupling of sterically and electronically diverse aryl chlorides with organo tin reagents, their protocol was adapted in this work. However, unlike Buchwald reaction protocol, the catalytic system was not pre-milled. Test experiments were conducted by reacting 2-chloro- $10 \mathrm{H}$-phenothiazine $(1 \mathrm{mmol})$ with tributyl(2-thienyl)stannane $(1.2 \mathrm{mmol})$ in order to obtain 2(thiophen-2-yl)-10H-phenothiazine 16 under a variety of conditions. Applying catalytic loadings of $4 \mathrm{~mol} \% \mathrm{Pd}$ (OAc) 2 and $7 \mathrm{~mol} \%$ XPhos four experiments were set up using $3 \mathrm{mmol}$ of Tetrabutylammoniumfluoride (TBAF), CsF, $\mathrm{K}_{3} \mathrm{PO}_{4}$, and $\mathrm{K}_{2} \mathrm{CO}_{3}$ respectively and $3 \mathrm{~mL}$ of 1,4-dioxane under $\mathrm{N}_{2}$ atmosphere at the temperature of $80^{\circ} \mathrm{C}$ and reaction progress monitored with thin-layer chroma-tography. Full conversion of starting materials was ob-served within $4 \mathrm{~h}$ with $\mathrm{CsF}$, about $50 \%$ conversion with $\mathrm{K}_{3} \mathrm{PO}_{4}$ and $\mathrm{K}_{2} \mathrm{CO}_{3}$ and none were recorded for TBAF even when reaction time was extended to $8 \mathrm{~h}$. Yellow solid was isolated in $80 \%$ yield after reaction work-up and purifica-tion by flash column chromatography on silica gel using $20 \%$ dichloromethane$80 \%$ petroleum ether solvents. Spectroscopic and elemental analysis data correspond to molecular structure of compound and formula, $\mathrm{C}_{16} \mathrm{H}_{11} \mathrm{NS}_{2}$. The proton nuclear magnetic spectra integra-tion traces were consistent with 11 protons and in harmony with carbon signals supplied by carbon-13 nuclear mag-netic resonance spectroscopy. This was further validated by molecular ion peak with $\mathrm{m} / \mathrm{z} 281.0339$ [(100), $\mathrm{M}^{+}$, found in mass spectrum. There was no significant differ-ence in product yield when toluene and tertiary butanol sol-vents were used with CsF instead of 1,4-dioxane. The reaction scope was also expanded by coupling 2-chloro$10 \mathrm{H}$-phenothiazine $(1 \mathrm{mmol})$ with tributylfuranylstannane 13 to obtain $77 \%$ isolated yield of 2-(2-furanyl)- $10 \mathrm{H}$-phenothiazine 20 . Compound 20 is a shiny yellow powdery solid. It was believed the use of CsF enhanced the reaction rate as well the corresponding yields of the product be-cause recent findings have associated increased reactivity

Scheme 1. Synthesis of reaction intermediates.

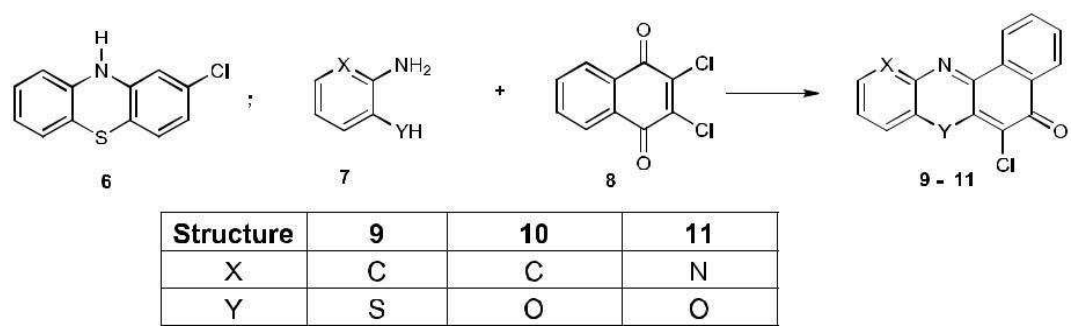


in Stille reactions to fluoride additive [43]. This was attributed to the formation of hypervalent fluorostannane anions 14, which undergo labile transmetalation reactions (Scheme 2).

Buchwald practically recorded greatest enhancement with $\mathrm{CsF}$ [42]. Encouraged by these procedural develop-ments, we applied them as a general protocol for the cou-pling of chlorophenothiazine and chlorophenoxazine substrates with organotin, but the reaction failed with the angular-fused chlorophenothiazines and chlorophe noxazines (9-11), generating only trace conversions. Ini-tially, the failure of the reaction protocol to couple nonlin-ear chlorophenothiazine and chlorophenoxazine substrates with organotin was attributed to the inability of the cata-lytic system to activate the aryl halide toward oxidative ad-dition, which is generally known to be a crucial stage in the catalytic cycle. Hence, a modified protocol was sought. In this procedure, the catalyst and ligand was charged in a $10 \mathrm{~mL}$ round bottom (RB) flask and corked with rubber septum followed by air evacuation and corresponding back filling with $\mathrm{N}_{2}$ gas four times before addition of predegassed solvent followed by warming to $50^{\circ} \mathrm{C}$ within $10 \mathrm{~min}$. The rubber septum was immediately removed from flask to add $\mathrm{ArCl}$ and $\mathrm{CsF}$ and replaced again. This was followed by injection of $1.2 \mathrm{mmol}$ of organostannane, and the reaction temperature was maintained under inert atmo-sphere for $30 \mathrm{~min}$ before increasing to $80^{\circ} \mathrm{C}$. The isolated

Scheme 2. Formation and reaction of hypervalent fluoro-(2-thienyl) stannane anion.

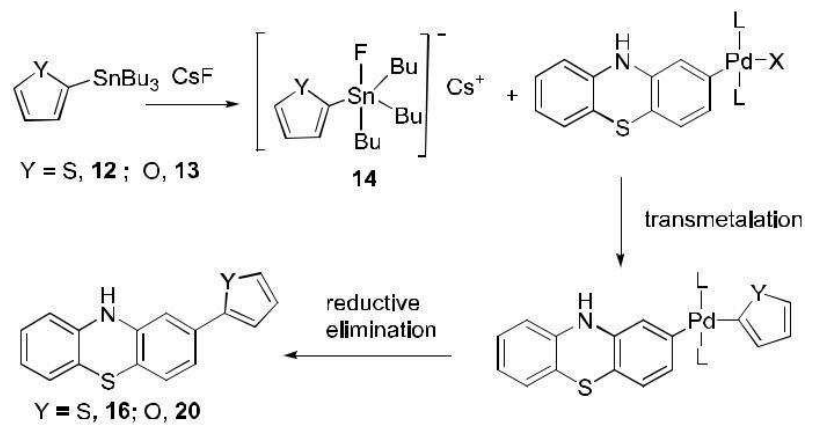

products at the completion of the reaction gave over $70 \%$ yields dehalogenated product instead of 6-thiophenyl or 6-furanyl substituted products. For example, the reaction of 6-chloro-5H-benzo[a]phenothiazin-5-one 9 with tributylthienylstannane 12 gave $5 \mathrm{H}$ benzo[a]phenothiazin-5-one 15 (Scheme 3). The proton nuclear resonance spec-trum integrated accurately for nine aromatic protons with the proton in position 6 of the compound 15 found unusu-ally upfield at $6.75 \mathrm{ppm}$ probably due to the additive shielding effects conferred on it by the ring current and the carbonyl functional group.

The failure of the reaction to provide desired products compelled us to search for an alternative protocol to couple organostannanes to 6-chlorobenzo[a]phenothiazines and 6chlorobenzo[a]phenoxazines 9-11 (Scheme 3). Reasoning $\mathrm{C}-\mathrm{Sn}$ bond is more polar than $\mathrm{C}-\mathrm{B}$, we expected an enhanced transmetalation step for cross-coupling organos tannanes over organoboranes. With this hypothesis, we invoked earlier reaction protocol [39] employed in crosscoupling of angular phenothiazine/phenoxazine chlorides with organoboranes to afford moderate isolated yields of derivatized products. The yield was further improved by first preactivating the catalyst-ligand system by warming in aqueous acetonitrile to $50^{\circ} \mathrm{C}$ before adding $\mathrm{K}_{2} \mathrm{CO}_{3}, \mathrm{ArCl}$, and organostannane, and the reaction continued until satisfactory consumption of starting materials was observed (Scheme 4).

Encouraged by the result of this tested procedure, it was extended to the coupling of angular chloropheno thiazine/chlorophenoxazines with organostannane, and the results are presented in Table 1. The results show that moderate to high yields of derivatized products were obtained applying the developed procedure to five coupling reactions. The coupling of 2-chloro- $10 \mathrm{H}$-phenothiazine substrate with organostannanes gave the highest yields of products in shorter time and this may be attributed to higher electrophilicity as well as freer access to the reaction site of the substrate. The proton nuclear magnetic reso-nance spectroscopic chemical shifts for the aromatic protons of products 16-22 appeared in the range of 8.88$6.54 \mathrm{ppm}$ with the integration traces in agreement with

Scheme 3. $\mathrm{Pd}(0) / \mathrm{XPhos}-$ catalyzed Stille cross-coupling under various conditions.

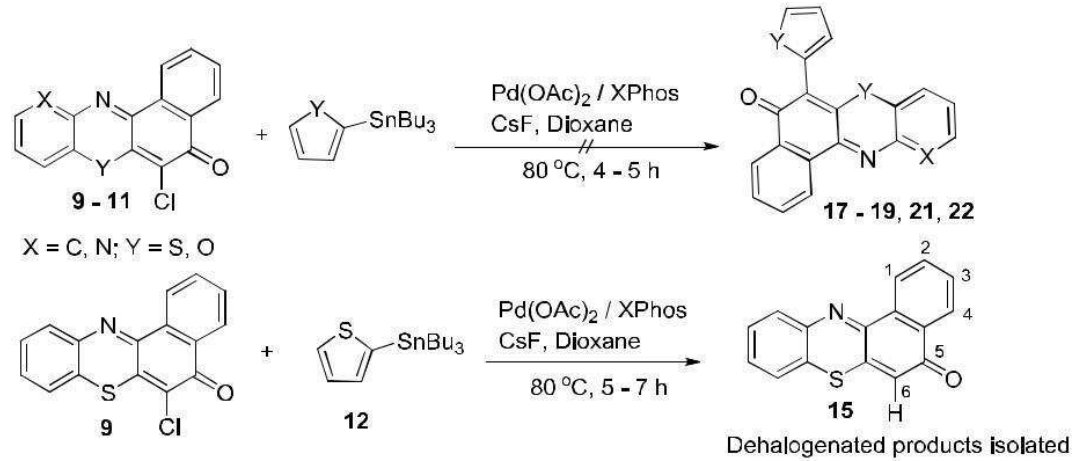


Scheme 4. $\operatorname{Pd}(0) / X P h o s$ catalyzed Stille preactivated reaction.
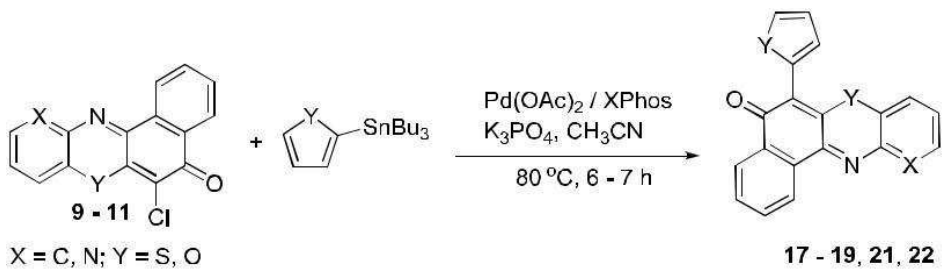

Table 1

Stille cross-coupling of chlorophenothiazines and chlorophenoxazines ${ }^{\mathrm{a}}$.

\begin{tabular}{|c|c|c|c|c|c|}
\hline Entry & Aryl chloride & Organotin & Product & Time (h) & Yield $^{\mathrm{b}}(\%)$ \\
\hline 1 & & & & 4 & 81 \\
\hline 2 & & 12 & & 6 & 53 \\
\hline 3 & & 12 & & 6 & 73 \\
\hline 4 & & 12 & & 6 & 78 \\
\hline 5 & & & & 5 & 77 \\
\hline 6 & & 13 & & 6 & 67 \\
\hline 7 & & 13 & & 6 & 70 \\
\hline
\end{tabular}

${ }^{\mathrm{a}}$ Reaction conditions: chlorophenothiazine/chlorophenoxazine (1.0 equiv), organotin (1.5 equiv.), $\mathrm{K}_{3} \mathrm{PO}_{4}$ (3 equiv), $\mathrm{CH}_{3} \mathrm{CN}(3 \mathrm{~mL}), \mathrm{Pd}(\mathrm{OAc}) 2(4$ $\mathrm{mol} \%$ ), and XPhos (7 mol\%). Entries 1 and 5: $\mathrm{CsF}$ (3 equiv) was used instead of $\mathrm{K}_{3} \mathrm{PO}_{4}$.

${ }^{\mathrm{b}}$ Isolated yield after purification by flash column chromatography. 


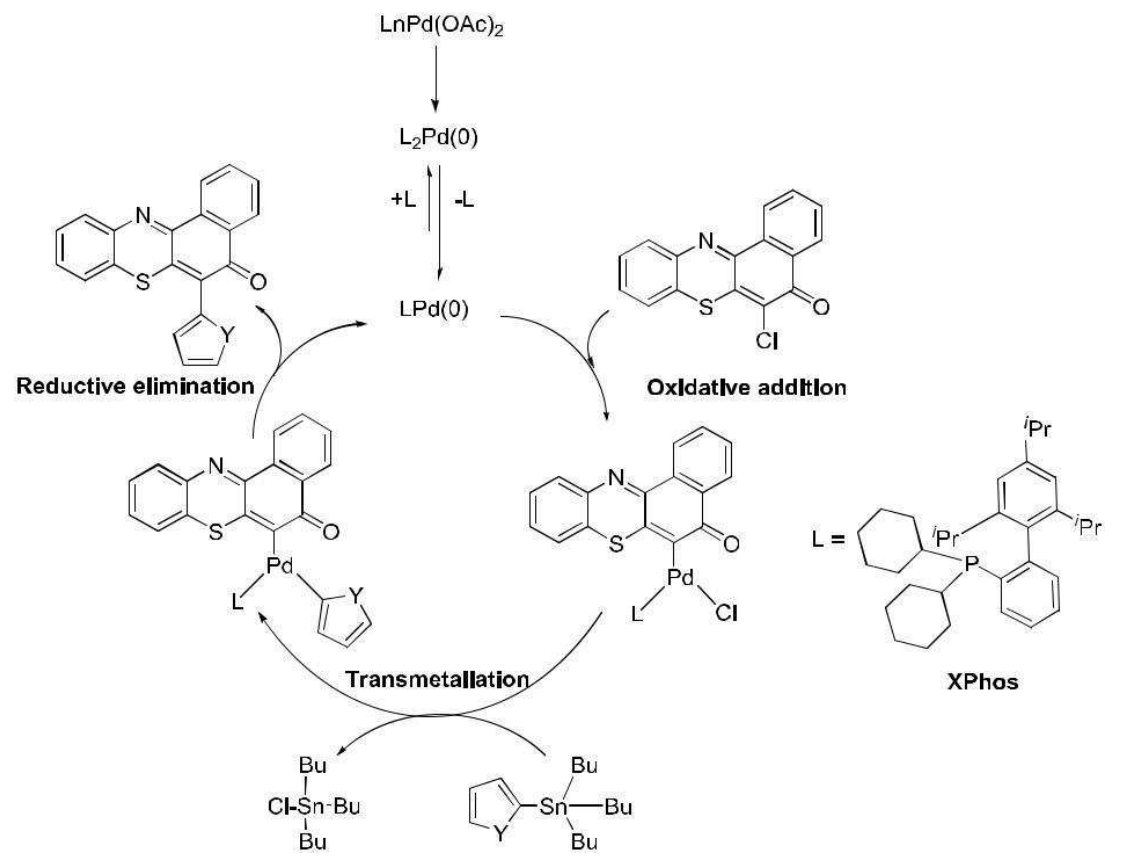

the number of protons in the respective compounds. These results were nicely substantiated by carbon nuclear mag-netic spectroscopic data, which furnished the number of peaks corresponding to the number of carbons in each compound in the range of 181.98-109.49 ppm. The carbonyl carbon of each compound were distinguishable from the rest and were found in 178.47, 181.91, 181.02, and $180.98 \mathrm{ppm}$ at higher frequency than other $\mathrm{sp}^{2}$ hybridized carbons, indicating that the carbonyl groups were well tolerated.

The prepared compounds were all colored and have strong absorptions in the visible region of the electromagnetic spectra $(400-800 \mathrm{~nm})$. They also exhibit slight red shifts due to their extended conjugations. Phenothiazine derivatives with extended $\pi$-conjugated substituents often display intense luminescence upon UV/vis excitation with Stokes shifts that might be due to solvent relaxation and, in part, to geometry changes in the excited state [25]. The electronic properties of these compounds have led to their applications as electrophore probes in supramolecular assemblies for photoinduced electron transfer and sensor studies and as electron-donor components in material scientific investigations such as electrically conducting charge-transfer composites, polymers, Do-Acc arrangements, and also as chromophores in dye-sensitized photovoltaic cells [26]. Furthermore, derivatives 16-22 were found to be good colorants for textiles, papers, paint, ink, soap, polish, candle, and plastic and cosmetic products.

By using 6-chloro-5H-benzo[a]phenothiazine 9 electrophilic substrate, we propose a general plausible mechanism for the syntheses of derivatives 17-19, 21, and 22 (Scheme 5).

The reduction of compounds $17-19,21$, and 22 to their corresponding angular phenothiazinols/phenoxazinols was accomplished by using sodium dithionite. For example, 17 easily loses its reddish color on refluxing in sodium dithionite due to the formation of 6-(thiophen-2-yl)-12Hbenzo[a]phenothiazin-5-ol compound 23 (Scheme 6). However, the reduced yellowish compound was too unstable to be isolated in their pure forms as they easily reverted under atmospheric condition to the intensely reddish colored oxidized iminoquinoid compound. This property makes the synthesized derivatives applicable as vat dyes.

Scheme 6. Reduction of thiophenylbenzophenothiazinone to thiophenylbenzophenothiazinol.

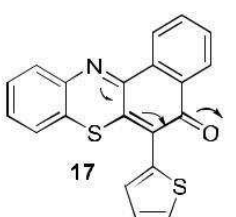

6-(thiophen-2-yl)-5H-benzo[a]phenothiazin-5-on

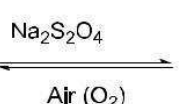

Air $\left(\mathrm{O}_{2}\right)$

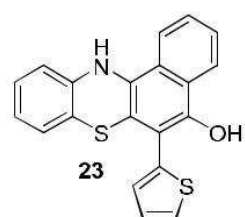

6-(thiophen-2-yl)-12H-benzo[a]phenothiazin-5-ol 


\section{CONCLUSION}

New and highly colored phenothiazine and phenoxazine dyes were prepared from $\mathrm{Pd}(0) / \mathrm{XPhos}$-catalyzed crosscoupling of chlorophenothiazines/chlorophenoxazines with organotins in moderate to high yields at relatively mild temperature. These dyestuffs were found to be good colorants for textiles, papers, paint, ink, soap, polish, can-dle, plastic and cosmetic materials.

\section{EXPERIMENTAL}

General information. All chemicals were purchased from Aldrich Chemical Company, UK, and were used without further purification. Otherwise stated, all compounds were synthesized and characterized in the School of Chemistry of Cardiff University, UK. Melting points were determined with a Fischer-Johns apparatus. ${ }^{1} \mathrm{H}$ and ${ }^{13} \mathrm{C}$-NMR data were recorded with Brucker DPX $400 \mathrm{MHz}$ spectrometers relative to tetramethylsilane as internal standard. All chemical shifts are reported in ppm $(\delta)$, and coupling constants $(\mathrm{J})$ are reported in hertz. Multiplicity is indicated using the following abbreviations: br for broad, $\mathrm{s}$ for singlet, $\mathrm{d}$ for doublet, $\mathrm{t}$ for triplet, dd for doublet of doublets, and $\mathrm{m}$ for multiplet. The mass spectra data were obtained on a Varian 1200 Quadruple Mass and Micromass Quadro II spectrometers. Elemental analysis was carried out with Thermo Quest Flash 1112 series (CHNS) Elemental Analyzer. UVVisible spectra were recorded on Cecil 7500 Aquarius 7000 Series Spectrometer at Chemistry Advance Laboratory, Sheda Science and Technology Complex (Shestco) Abuja, Nigeria, using matched $1 \mathrm{~cm}$ quartz cells and methanol as solvent. The absorption maxima are recorded in nanometers $(\mathrm{nm})$ and figures in parenthesis are $\log \varepsilon$.

Synthesis of angular phenothiazine and phenoxazine intermediates. 6-Chloro-5H-benzo[a]phenothiazin-5-one (9). To a suspension of 2-aminothiophenol (2.5 g, $20 \mathrm{mmol})$ in chloroform $(50 \mathrm{~mL})$ was added $\mathrm{Na}_{2} \mathrm{CO}_{3}(2.12 \mathrm{~g}, 20$ mmol) and the mixture warmed to boiling before addition of 2,3-dichloro-1,4-naphthoquinone (4.54 g, $20 \mathrm{mmol}$ ), and the entire mixture refluxed for $3 \mathrm{~h}$ while stirring with magnetic bar. The reaction mixture was cooled to room temperature, and solvent was distilled off in vacuum. Water $(25 \mathrm{~mL})$ was added to the dark solid stirred and filtered to remove inorganic salts and air-dried. The solid was recrystallized from benzene-toluene after treatment with activated charcoal to obtain reddish brown shiny solid $\left(5.01 \mathrm{~g}, 84 \%\right.$ ), mp $228-230^{\circ} \mathrm{C}$ (Lit. ${ }^{44} 232^{\circ} \mathrm{C}$ ). $\delta_{\mathrm{H}}$ (400 $\left.\mathrm{MHz} \mathrm{CDCl}_{3}\right)$ : 8.87-8.84 (1H, m); 8.33-8.31 (1H, $\mathrm{m})$; 7.97-7.94 (1H, m), 7.74-7.72 (2H, m); 7.54-7.42 $(3 \mathrm{H}, \mathrm{m}) . \delta_{\mathrm{c}}\left(150 \mathrm{MHz} \mathrm{CDCl}_{3}\right): 173.85$ (carbonyl carbon), 143.80, 138.41, 135.20, 134.10, 133.29, 132.00, 131.62,
$130.21,128.34,126.53,125.97,125.33,125.18,123.55$. UV-Visible $\lambda_{\max }(\mathrm{MeOH}): 381.5$ (4.06); 479 (3.21); 747.5 (3.97). IR ( $\left.\mathrm{V}_{\max }, \mathrm{cm}^{1}\right)$ : 1640, 1593, 1578, 1510, 1290, 1155, 1090, 905, 855, 828, 777, 721, 681, 644. Found: C, 64.57; H, 2.74; N, 4.72; S, 10.79\%. Molecular formula $\mathrm{C}_{16} \mathrm{H}_{8} \mathrm{CINOS}$ requires $\mathrm{C}, 64.54 ; \mathrm{H}, 2.71 ; \mathrm{N}$, $4.70 ; \mathrm{S}, 10.77 \%$.

6-Chloro-5H-benzo[a]phenoxazin-5-one (10). A mixture of 2-aminophenol $(2.18 \mathrm{~g}, 20 \mathrm{mmol})$ and $\mathrm{KOH} \quad(2.24 \mathrm{~g}$, $20 \mathrm{mmol}$ ) was stirred at room temperature for $0.5 \mathrm{~h}$ in methanol $(100 \mathrm{~mL})$ followed by addition of 2,3-dichloro1,4-naphthoquinone $(4.54 \mathrm{~g}, 20 \mathrm{mmol})$, and the entire reaction mixture was stirred at room temperature for $6 \mathrm{~h}$. The solvent was distilled off in vacuum, and water (50 $\mathrm{mL}$ ) was added to the yellowish brown solid, stirred, and filtered and solid further wash with $25 \mathrm{~mL}$ of $5 \% \mathrm{HCl}$ and air-dried. The crude product was recrystallized from benzene-toluene after treatment with activated charcoal to give yellow-orange colored solid, yield $4.85 \mathrm{~g}$ (86\%), $\mathrm{mp}$ $199-201^{\circ} \mathrm{C}$ (Lit. $\left.{ }^{45} 203^{\circ} \mathrm{C}\right) . \delta_{\mathrm{H}}\left(400 \mathrm{MHz}, \mathrm{CDCl}_{3}\right): 8.68-$ $8.66(1 \mathrm{H}, \mathrm{m}) ; 8.31-8.29(1 \mathrm{H}, \mathrm{m}) ; 7.81-7.79(1 \mathrm{H}, \mathrm{dd}, \mathrm{J}=$ $7.80,7.81)$; 7.76-7.68 (2H, m); 7.49- 7.46 (1H, m); 7.41-7.33 (2H, m). $\delta_{\mathrm{c}}\left(150 \mathrm{MHz}^{\mathrm{CDCl}} 3\right): 177.46(\mathrm{C} 1 / 4 \mathrm{O})$, $146.89,146.15,143.80,132.63,132.41,132.09,131.85$, $131.44,130.27,129.93,126.63,125.85,124.94,116.19$. UV-Vis $\lambda_{\max }(\mathrm{MeOH}): 354.5$ (3.88); 440 (3.54); 747 (4.01). IR ( $\left.\mathrm{V}_{\max }, \mathrm{cm}^{1}\right)$ : 1640, 1570, 1330, 1310, 1280, 1250, 1150, 1100, 1010, 920, 840, 780, 760, 690. (Found: C, 68.92; H, 2.77; N, 4.78. Molecular formula $\mathrm{C}_{16} \mathrm{H}_{8} \mathrm{ClNO}_{2}$ requires $\mathrm{C}, 68.22 ; \mathrm{H}, 2.86 ; \mathrm{N}, 4.97 \%$ ).

6-Chloro-5H-naphtho[2,1-b]pyrido[2,3-e][1,4] oxazin-5-one (11). By a similar method to the synthesis of 4, 6-chloro-5Hnaphtho[2,1-b]pyrido[2,3-e]oxazin-5-one was prepared from 2-aminopyridin-3-ol (2.20 g, $20 \mathrm{mmol})$, 2,3-dichloro-1,4naphthoquinone (4.54 g, $20 \mathrm{mmol})$, and $\mathrm{KOH}(2.24 \mathrm{~g}, 20$ $\mathrm{mmol})$ in methanol $(100 \mathrm{~mL})$ as a yellow-orange solid, recrystallized from acetone after treatment with activated carbon (yields $4.47 \mathrm{~g}, 81 \%)$, mp $207-208^{\circ} \mathrm{C}$. $\delta_{\mathrm{H}}(400 \mathrm{MHz}$ $\left.\mathrm{CDCl}_{3}\right)$ : 8.84-8.82 $(1 \mathrm{H}, \mathrm{m}) ; 8.62-8.61(1 \mathrm{H}, \mathrm{dd}, \mathrm{J}=8.61$, 8.64); 8.32-8.30 (1H, m); 7.79-7.76 (3H, m), 7.45-7.43 $(1 \mathrm{H}, \mathrm{d}, \mathrm{J}=7.45) . \delta_{\mathrm{c}}\left(150 \mathrm{MHz} \mathrm{CDCl}_{3}\right): 177.27$ (carbonyl carbon), 150.23, 147.27, 146.09, 144.37, 140.68, 133.11, $132.93,131.37,129.83,126.82,126.21,125.95,124.59$, 115.90. UV-Visible $\lambda_{\max }(\mathrm{MeOH}): 350.5$ (3.38); 441.0 (3.47); 746 (4.03). IR ( $\left.\mathrm{V}_{\max }, \mathrm{cm}^{1}\right)$ : 1650, 1565, 1560, 1555, 1420, 1330, 1900, 1270, 1230, 1120, 1100, 1030, 920, 870, 810, 775, 710, 690. (Found: C, 68.31; H, 2.89; N, 5.01\%.

Molecular formula $\mathrm{C}_{16} \mathrm{H}_{8} \mathrm{ClNO}_{2}$ requires $\mathrm{C}$, 68.22; H, 2.86; N, 4.97).

General procedures for Stille reactions: Method 1.

To an

oven-dried $10 \mathrm{~mL}$ RB flask was added Pd(OAc)2 (8.92 mg, 4 mol\%), XPhos (32.5 mg, $7 \mathrm{~mol} \%$ ), chlorophenothiazine (234 $\mathrm{mg}, 1 \mathrm{mmol} \%$ ), and $\mathrm{CsF}$ (459 mg, $3 \mathrm{mmol}$ ), and the vessel was covered with a rubber septum. The flask was 
evacuated and backfilled with $\mathrm{N}_{2}$ thrice before injection of degassed dioxane or toluene $(3 \mathrm{~mL})$ and, as temperature of reaction mixture was gradually heated to $50^{\circ} \mathrm{C}$ tributyl-(2thienyl)stannane $(1.2 \mathrm{mmol})$, was injected into the flask. The temperature was maintained for $30 \mathrm{~min}$ before increasing to $80^{\circ} \mathrm{C}$. The reaction was terminated in $4 \mathrm{~h}$ and cooled to room temperature. Reaction mixture was diluted with DCM $(3 \mathrm{~mL})$ and extracted from water $(5 \mathrm{~mL})$ with $5 \mathrm{~mL}$ of DCM four times. The combined

organic extract was dried with $\mathrm{MgSO}_{4}$ and concentrated

in vacuum. The crude product was purified by flash chromatography on silica gel using petroleum etherethyl acetate.

General procedures for Stille reactions: Method 2. An oven-dried $10 \mathrm{~mL}$ RB flask was charged with $\mathrm{Pd}(\mathrm{OAc}) 2$ (8.92 $\mathrm{mg}, 4 \mathrm{~mol} \%$ ) and XPhos (32.5 mg, $7 \mathrm{~mol} \%$ ) and covered with rubber septum. The vessel was evacuated and backfilled with $\mathrm{N}_{2}$ thrice before injecting $\mathrm{CH}_{3} \mathrm{CN}(2 \mathrm{~mL})$ and $\mathrm{H}_{2} \mathrm{O}(1 \mathrm{~mL})$ (both solvents degassed for $30 \mathrm{~min}$ ), and the reaction mixture warmed to $50^{\circ} \mathrm{C}$ within $10 \mathrm{~min}$. Rubber septum was quickly removed to charge with chlorophenothiazine (1 mmol) and $\mathrm{K}_{3} \mathrm{PO}_{4}$ (318 mg, $1.5 \mathrm{mmol}$ ) and replaced before injecting tributyl thienyl Istannane or tributyl furanyl stannane $(1.2 \mathrm{mmol})$. The temperature was maintained for $30 \mathrm{~min}$ before increasing to $80^{\circ} \mathrm{C}$. The reaction was terminated in $5 \mathrm{~h}$ and diluted with DCM $(5 \mathrm{~mL})$, and the crude product was extracted from water $(5 \mathrm{~mL})$ four times with DCM. The combined organic extract was dried with $\mathrm{MgSO}_{4}$ and concentrated in vacuum. The crude product was purified by flash chromatography on silica gel using petroleum ether-ethyl acetate eluent.

2-(Thiophen-2-yl)-10H-phenothiazine (16) (Table 1, entry 1). Method 1 was applied to convert tributyl 2thienyl stannane and 2-chloro-10H-phenothiazine into the title product in $4 \mathrm{~h}$. Purification by flash chromatography (5\% EtOAc/ $95 \%$ pet. ether eluent) supplied the analytically pure yellow solid product $(227.61 \mathrm{mg}, 81 \%), \mathrm{mp} 188-189^{\circ} \mathrm{C}$. NMR: $\delta_{H}(400 \mathrm{MHz}$, acetone-d6): 7.80 (1H, br, s); 7.28-7.27 $(1 \mathrm{H}, \quad \mathrm{dd}, \mathrm{J}=7.27,7.27) ; 7.22-7.20(1 \mathrm{H}, \mathrm{d}, \quad \mathrm{J}=7.21)$; 6.99-6.94 (2H, m); 6.89-6.86 (4H, m); 6.69-6.59 (2H, m). $\delta_{\mathrm{c}}(150 \mathrm{MHz}$, acetone-d6): 144.35, 143.78, 142.90, 134.65, $129.01,128.41,128.28,127.64,127.20,125.63,123.95$, $123.06,120.20,118.40,118.17,115.58,112.37$. UVVisible $\lambda_{\max }(\mathrm{MeOH}): 492.5$ (4.03); 747.5 (3.99). HRMS (EI), $\mathrm{m} / \mathrm{z}(\%$ relative intensity): $83.0773 \quad(2.0), 118.5283$ (3.0), 140.5161 (7.0), 167.0773 (2.0), 191.0729 (3.0), 204.0827 (13.0), 217.0921(5.0), 236.0547 (23), 266.0150 (2.0), 281.0339 [(100), M ]. (Found: $\stackrel{+}{\mathrm{C}}, 68.37 ; \mathrm{H}, 4.03 ; \mathrm{N}$, $5.01 ; \mathrm{S}, 22.86 \%$. Molecular formula $\mathrm{C}_{16} \mathrm{H}_{11} \mathrm{NS}_{2}$ requires $\mathrm{C}$, 68.30; H, 3.94; N, 4.98; S, 22.79.)

6-(Thiophen-2-yl)-5H-benzo[a]phenothiazin-5-one

(Table 1, entry 2). Method 2 was used to convert tributyl 2-thienyl stannane and 6-chloro-5H-benzo[a]phenothiazin- chromatography employing $10 \%$ EtOAc/90\% pet. ether as eluent gave analytically pure dark brown solid product, yield $183 \mathrm{mg} \quad(53 \%), \mathrm{mp}>200^{\circ} \mathrm{C}(\mathrm{dec})$. NMR: $\delta_{\mathrm{H}}$ $\left(400 \mathrm{MHz}, \mathrm{CDCl}_{3}\right): \quad 8.88-8.85(1 \mathrm{H}, \mathrm{m}) ; 8.31-8.29(1 \mathrm{H}$, m); 7.91-7.89 (1H, d, J = 7.90); 7.76-7.67 (2H, m); 7.56$7.54(1 \mathrm{H}, \mathrm{dd}, \mathrm{J}=7.55,7.51) ; 7.44-7.40(1 \mathrm{H}, \mathrm{m}) ; 7.37-$ $7.32(1 \mathrm{H}, \mathrm{dd}, \mathrm{J}=7.28,7.18) ; 7.18-7.17(3 \mathrm{H}, \mathrm{m})$. $\mathbf{\delta}_{\mathrm{C}}$ (150 MHz, $\left.\mathrm{CDCl}_{3}\right): 178.47, \quad 144.77,138.41,136.95$, $134.61,134.34,132.17,131.77,131.38,129.87,129.04$,

$128.41,127.88,126.84,125.65$, 125.07,124.88, 124.88, 123.67. HRMS (EI), $\mathrm{m} / \mathrm{z}$ (\% relative intensity): 83.9667 (100), 149.0583 (3), 207.0481 (3), 284.0637 (4), 316.0423 (7), 345.0280 [(30), $\left.\mathrm{M}^{+}\right]$. UV-Visible $\lambda_{\max }(\mathrm{MeOH}): 369.0$ (3.11); 484.5 (4.04); 743.5 (3.77). (Found: C, 69.61; H, $3.19 ; \mathrm{N}, 4.01 ; \mathrm{S}, 18.59 \%$. Molecular formula $\mathrm{C}_{20} \mathrm{H}_{11} \mathrm{NOS}_{2}$ requires $\mathrm{C}, 69.54 ; \mathrm{H}, 3.21 ; \mathrm{N}, 4.05 ; \mathrm{S}, 18.56$.)

6-(Thiophen-2-yl)-5H-benzo[a]phenoxazin-5-one

(Table 1 , entry 3 ).

Method 2 was used to prepare the title product from the cross-coupling of tributyl 2-thienyl stannane with 6-chloro-5H-benzo[a]phenoxazin-5-one in $6 \mathrm{~h}$. Purification by flash chromatography applying $10 \%$ EtOAc/90\% pet. ether as eluent provided the analytically pure dark brown solid product, yield $240 \mathrm{mg}$ (73\%), mp 203-204 ${ }^{\circ} \mathrm{C}$. NMR: $\delta_{\mathrm{H}} \quad\left(400 \mathrm{MHz}, \mathrm{CDCl}_{3}\right)$ : 8.57-8.65 $(1 \mathrm{H}, \mathrm{m}) ; 8.33-8.31(1 \mathrm{H}, \mathrm{m}) ; 8.22-8.20$ (1H, dd, J = 8.21, 8.21); 7.79-7.77 (1H, dd, J = 7.74, 7.74); 7.72-7.68 (2H, m); 7.52-7.50 (1H, dd, J = 7.51-7.47); 7.47-7.39 (2H, m); 7.34-7.30 (1H, m); 7.19-7.16 (1H, m). $\delta_{\mathrm{c}}(150 \mathrm{MHz}$, $\left.\mathrm{CDCl}_{3}\right)$ : $181.91\left(\mathrm{C}^{1} / 4 \mathrm{O}\right), 146.85,145.05,143.85,132.89$,

132.09, 131.81, 131.78, 131.67, 131.35, 130.07, 129.60,

$128.63,126.62,126.22,125.55,124.43,115.85,112.73$. UV-Visible $\lambda_{\max }(\mathrm{MeOH}): \quad 364.5$ (4.08); 493.0 (3.64); 750.0 (4.02). HRMS (EI), m/z (\% relative intensity):

83.9533 (100), 142.5381 (8), 174.0802 (3), 240.0802 (3), 272.0522 (10), 301.0556 (12), 329.0512 [(93), $\left.\mathrm{M}^{+}\right]$.

(Found: C, 72.98; H, 3.40; N, 4.31\%. Molecular formula $\mathrm{C}_{20} \mathrm{H}_{11} \mathrm{NO}_{2} \mathrm{~S}$ requires $\mathrm{C}, 72.93 ; \mathrm{H}, 3.37 ; \mathrm{N}, 4.25 ; \mathrm{S}, 9.73$.)

6-(Thiophen-2-yl)-5H-naphtho[2,1-b]pyrido[2,3-e][1,4]oxazin5-one (19) (Table 1, entry 4). Method 2 was used to crosscouple tributyl 2-thienyl stannane with 6-chloro-5Hnaphtho[2,1-b]pyrido[2,3-e][1,4]oxazin-5-one to afford the title product within $6 \mathrm{~h}$. Purification by flash chromatography (45\% EtOAc/ $55 \%$ pet. ether eluent) gave the analytically pure dark brown solid product, yield $257 \mathrm{mg}(78 \%), \mathrm{mp}>210^{\circ} \mathrm{C}(\mathrm{dec})$. NMR: $\delta_{\mathrm{H}}(400 \mathrm{MHz}$, $\left.\mathrm{CDCl}_{3}\right)$ : 8.76-8.74 (1H, m); 8.55-8.53 (1H, dd, J = 8.54, $8.54) ; 8.26-8.24(1 \mathrm{H}, \mathrm{m}) ; 8.14-8.13(1 \mathrm{H}, \mathrm{dd}, \mathrm{J}=8.14)$; $7.72-7.67$ (2H, m); 7.51-7.49 (1H, dd, J = 7.50, 7.50); 7.38-7.35 (1H, dd, J = 7.37, 7.30); 7.13-7.11 (1H, dd,

$\mathrm{J}=7.12, \quad 7.10) . \quad \delta_{\mathrm{c}}\left(600 \mathrm{MHz}, \mathrm{CDCl}_{3}\right): 181.95\left(\mathrm{C}^{1 / 4 \mathrm{O}}\right)$, 151.08, 146.95, 144.74, 144.01, 140.63, 132.81, 132.60,

$131.58,131.21,130.77,130.27,129.52,126.76,126.41$, 125.73, 125.41, 124.12, 113.81. UV-Visible $\lambda_{\max }$ (MeOH): 370.0 (3.81); 506.0 (3.24); 745.0 (3.87). HRMS 
(100), 301.0420 (2), $330.0464\left[(100), \mathrm{M}^{+}\right]$. (Found: C, $69.11 ; \mathrm{H}, 3.07 ; \mathrm{N}, 8.51 ; \mathrm{S}, 9.74 \%$. Molecular formula $\mathrm{C}_{19} \mathrm{H}_{10} \mathrm{~N}_{2} \mathrm{O}_{2} \mathrm{~S}$ requires $\mathrm{C}, 69.08 ; \mathrm{H}, 3.05 ; \mathrm{N}, 8.48 ; \mathrm{S}$, $9.70 \%$.)

2-(Furan-2-yl)-10H-phenothiazine (20) (Table 1, entry 5). Method 1 was used to convert tributyl furan-2yl stannane and 2-chloro- $10 \mathrm{H}$-phenothiazine into the title product in $5 \mathrm{~h}$. Analytically pure product obtained by flash chromatography $(5 \%$ EtOAc/95\% pet. ether eluent) as yellow solid, yield $204 \mathrm{mg}(77 \%), \mathrm{mp} 174-176^{\circ} \mathrm{C}$. NMR: $\delta_{\mathrm{H}}$ (400 MHz, acetone-d6): $7.83(1 \mathrm{H}, \mathrm{br}, \mathrm{s}) ; 7.43-7.43(1 \mathrm{H}$, dd, $\mathrm{J}=7.43,7.43) ; 7.01-6.98(1 \mathrm{H}, \mathrm{dd}, \mathrm{J}=7.00,7.00)$; 6.87-6.78 $(3 \mathrm{H}, \mathrm{m}) ; 6.67-6.56(3 \mathrm{H}, \mathrm{m}) ; 6.37-6.35$ (1H, dd, 6.36, 6.36). $\delta_{\mathrm{c}}(150 \mathrm{MHz}$, acetone-d6): 154.19, 143.66, 143.39, 143.13, $142.98,131.18,128.39,127.20,123.02,118.40,118.20$, 117.71, 115.57, 112.64, 110.33, 106.02. UV-Visible $\lambda_{\max }$ (MeOH): 747.0 (4.10). (Found: C, 72.47; H, 4.22; N, 5.21; S, $12.06 \%$. Molecular formula $\mathrm{C}_{16} \mathrm{H}_{11} \mathrm{NOS}$ requires $\mathrm{C}, 72.43$; H, 4.18; N, 5.28; S, 12.08.)

6-(Furan-2-yl)-5H-benzo[a]phenoxazin-5-one (21) (Table 1, entry 6). Method 2 was used to convert tributyl furanyl stannane and 6-chloro-5H-benzo[a]phenoxazin-5-one into the title product in $6 \mathrm{~h}$. Analytically pure product was provided by flash chromatography (10\% EtOAc/90\% pet. ether eluent) as a dark brown solid, yield $210 \mathrm{mg}(67 \%)$, mp $140-142^{\circ} \mathrm{C}$. NMR: $\delta_{\mathrm{H}}\left(400 \mathrm{MHz}, \mathrm{CDCl}_{3}\right)$ 8.62-8.60 $(1 \mathrm{H}, \mathrm{m}) ; 8.27-8.24(1 \mathrm{H}, \mathrm{m}) ; 7.72-7.63$ (3H, m); 7.59$7.58(1 \mathrm{H}, \mathrm{dd}, \mathrm{J}=7.58,7.58) ; 7.41-7.37(1 \mathrm{H}, \mathrm{m}) ; 7.30-$ $7.24(3 \mathrm{H}, \mathrm{m}) ; 6.55-6.54(1 \mathrm{H}, \mathrm{dd}, \mathrm{J}=6.55) . \delta_{\mathrm{c}}(150 \mathrm{MHz}$, $\left.\mathrm{CDCl}_{3}\right)$ : $181.02(\mathrm{C} 1 / 4 \mathrm{O}), 146.91,146.11,145.53,144.06$, 142. $61,132.96,131.99,131.78,131.32,130.73,129.54$, $126.42,125.34,124.45,116.13,114.89,111.40,109.49$. UV-Visible $\lambda_{\max }(\mathrm{MeOH}): 447$ (4.02). (Found: C, 72.62; $\mathrm{H}, 4.22 ; \mathrm{N}, 5.19 \%$. Molecular formula $\mathrm{C}_{16} \mathrm{H}_{11} \mathrm{NO}_{2}$ requires $\mathrm{C}, 72.43 ; \mathrm{H}, 4.18 ; \mathrm{N}, 5.23$.)

6-(Furan-2-yl)-5H-naphtho[2,1-b]pyrido[2,3-e][1,4]oxazin-

5 -one (22) (Table 1, entry 7). Method 2 was used to convert tributyl furanyl stannane and 6-chloro-5H-naphtho [2,1b]pyrido[2,3-e][1,4] oxazin-5-one to the title product within 6 h. Analytically pure product obtained by flash chromatography employing $50 \%$ EtOAc/50\% pet. ether eluent as a dark brown solid, yield $220 \mathrm{mg}(70 \%)$, mp 210$212^{\circ} \mathrm{C}$. NMR: $\delta_{\mathrm{H}}\left(400 \mathrm{MHz}, \mathrm{CDCl}_{3}\right)$ : 8.84-8.82 (1H, m); $8.57-8.56(1 \mathrm{H}, \mathrm{dd}, \mathrm{J}=8.56,8.56) ; 8.31-8.29(1 \mathrm{H}, \mathrm{m})$; 7.77-7.69 (3H, m); 7.62-7.61 (1H, dd, J = 7.61, 7.61); 7.40$7.34(2 \mathrm{H}, \mathrm{m}) ; 6.59-6.58(1 \mathrm{H}, \mathrm{dd}, \mathrm{J}=6.58,6.58) . \delta_{\mathrm{c}}(150$ $\left.\mathrm{MHz}, \mathrm{CDCl}_{3}\right): 180.98(\mathrm{C} 1 / 4 \mathrm{O}), 151.89,145.71,145.66$, $144.10,143.26,141.06,133.07,132.66,131.88,130.17$, $126.62,125.77,125.70,125.20,116.44,111.86,110.72$. UVVisible $\lambda_{\max }(\mathrm{MeOH}): 321.0$ (4.05); 459.5 (3.87). (Found: C, $72.83 ; \mathrm{H}, 3.17 ; \mathrm{N}, 8.78 \%$. Molecular

formula $\mathrm{C}_{1} 19 \mathrm{H}_{10} \mathrm{~N}_{2} \mathrm{O}_{3}$ requires $\mathrm{C}, 72.61 ; \mathrm{H}, 3.21 ; \mathrm{N}, 8.91$.)

Reduction of compounds 17-19, 21, and 22. In a typical experiment, compound 17 (345 mg, $1 \mathrm{mmol})$ was placed in a reaction flask containing water $(2 \mathrm{~mL})$ and acetone
(40 $\mathrm{mL})$. Sodium dithionite $(0.5 \mathrm{~g})$ was added, and the mixture was refluxed in a water bath for $1.5 \mathrm{~h}$. During the refluxing period, the color changed from red to yellow. The entire mixture was poured into a solution containing $0.5 \mathrm{~g}$ of dithionite in $100 \mathrm{~mL}$ of ice-cold water and stirred. This was quickly filtered by suction, but before the product could be collected from the filter paper, it had turned reddish. Analysis of the product confirmed it to be the starting iminoquinoid compound 17. This shows the reduced compound was auto-oxidized under this condition. Similar observations were seen in the case of compounds 18, 19, 21, and 22.

Acknowledgments. We thank the Petroleum Technology Development Funds (PTDF) for financial support and Cardiff University for a short-term research opportunity.

\section{REFERENCES AND NOTES}

[1] Okafor, C. O. Dyes Pigm 1986, 7, 249.

[2] Okafor, C. O. Int J Sulfur Chem B 1971, 6, 346.

[3] Bernthsen, A. Ber Deut Chem Ges 1883, 16, 2896.

[4] Bernthsen, A. Ber Deut Chem 1887, 20, 942.

[5] Okafor, C. O. Phosphorus Sulfur 1978, 4, 79.

[6] Smith, N. L. J Org Chem 1951, 16, 415.

[7] Rudnick, L. R., Ed. Lubricant Additives Chemistry \& Application, 2nd ed.; CRC Press, Taylor \& Francis Group: USA, 2009, p 7.

[8] West, H. L. J Inst Petroleum 1948, 34, 774.

[9] Murphy, C. M.; Ravner, H.; Smith, N. L. Ind Eng Chem 1950, $42,2479$.

[10] (a) Burford, B. L., Kander, O. S.; (Argus Chem. Corp.), Belgian Patent 665496, 1965; (b) Chem Abstr 1966, 64, 19902c.

[11] (a) Schnitzer, A. M.; Rensser, R. E. (Phillips Peteroleum Co.) US Patent 2,857,389, 21st Oct. 1958. (b) Chem Abstr 1959, 53, 52967.

[12] Campbell, F. L.; Sullivan, W. N.; Smith, L. E.; Haller, H. L. J Econ Entomol 1934, 27, 1176.

[13] Ricket, H. B.; Geiger, W.M. (Dow Chem. Co.) US Patent $2,945,856,1960$

[14] Knapp, W. A. US Patent 2,385,284, 1945.

[15] Rogers, W. P.; Cymerman-Craig, J.; Warwick, G. P. Brit J Pharmacol 1955, 23, 340.

[16] Okoro, U. C. Indian J Chem 1991, 30B, 22.

[17] Holmes, W. C.; Peterson, A. R. Strain Tech 1931, 6, 79.

[18] (a) Holmes, W. C. Amer Dyestuff Rept 1928, 17, 626; (b) Chem Abstr 1929, 23, 176.

[19] Frade, V. H. J.; Coutinho, P. J. G.; Moura, J. C. V. P.; Goncalves, M. S. T. Tetrahedron 2007, 63, 1654.

[20] Manneli, G.; Martini, E. Ann. Chim. (Rome) 1951, 41, 68.

[21] Okoro, U. C.; Onoabedje, E. A.; Odin, E. M. Inter J Chem $2009,19,197$.

[22] Okafor, C. O. Heterocycles 1977, 7, 391-392.

[23] Pluta, K.; Morak-Mlodawska, B.; Jelen, M. Eur. J. Med. Chem. 2011, 46, 3179-3189. 119.

[24] Ohlow, M. J.; Moosmann, B. Drug Discov Today 2011, 16,

[25] Meyer, T.; Ogermann, D.; Pankrath, A.; Kleinermanns, K.; Muller, T. J. J. J Org Chem 2012, 77, 3704.

[26] Kramer, C. S.; Zeitler, K.; Muller, T. J. J. Tetrahedron 2001, 42,8619 .

[27] Tacey, M.; Bernius, M.; Fletcher, R.; Kiszka, K.; Munger, S. O.; Brien, J. J Microelectron 2004, 25, 343. 
[28] Patil, V. S.; Padalkar, V. S.; Phatangare, K. R.; Umape, P. G.; Borase, B. N.; Sekar, N. J Heterocyclic Chem 2015, 52, 124.

[29] Jose, J.; K. Burgess, K. Tetrahedron 2006, 62, 11034.

[30] Sailer, M.; Franz, A. W.; Muller, T. J. J. Chem Eur J 2008, 14, 2602.

[31] Kramer, C. S.; Zeitler, K.; Muller, T. J. J. Org Lett 2000, 2, 3723.

[32] Turdean, R.; Bogdan, E.; Terc, A.; Petran, A.; Vlase, L.;

Turcu, I.; Grosu, I. Central Eur J Chem 2009, 7, 111.

[33] Franz, A. W.; Muller, T. J. J. Synthesis 2008, 2008, 1121.

[34] Kramer, C. S.; Zimmermann, T. J.; Sailer, M.; Muller, T. J. J. Synthesis 2002, 2002, 1163 .

[35] Hauck, M.; Turdean, R.; Memminger, K.; Schonhabor, J.; Rominger, F.; $\quad$ Muller, T. J. $\quad$ J. J Org Chem 2010, 75, 8591.
[36] Sailer, M.; Nonnenmacher, M.; Oeser, T.; Muller, T. J. J. Eur J Org Chem 2006423.

[37] Okafor, C. O.; Okoro, U. C. Dyes Pigm 1988, 9, 427.

[38] Okafor, C. O.; Okoro, U. C. Dyes Pigm 1991, 16, 149

[39] Onoabedje, E. A.; Okoro, U. C.; Knight, D. W.; Sarkar, A. J. Heterocyclic Chem. 2015 (in press), DOI 10.1002/jhet2485.

[40] Agarwal, N. L.; Mital, R. L. J. Chem. Engr. Data 1975, $20,199$.

[41] Ueno, Y.; Maeda, K.; Koshitani, J.; Yoshida, T. J Heterocyclic Chem 1982, 19, 167.

[42] Naber, J. R.; Buchwald, S. L. Adv Synth Catal 2008, 350, 957.

[43] Grasa, S. A.; Nolan, S. P. Org Lett 2001, 3, 119. 